\title{
PROBLEMATIKA PUSTAKAWAN MENGHADAPI MASA TRANSISI AKADEMI KEBIDANAN MENJADI SEKOLAH TINGGI ILMU KESEHATAN
}

\author{
Gina Agustina \\ Mahasiswa Pasca Sarjana UIN Sunan Kalijaga \\ e-mail: ggina11@gmail.com \\ Muhammad Yusrizal, S.IP \\ UIN Fatmawati Sukarno Bengkulu \\ e-mail: zaaquzwain@gmail.com
}

\begin{abstract}
Abstrak:
Artikel ini bertujuan untuk mengetahui problematika pustakawan dalam menghadapi masa transisi dari Akademi Kebidanan menuju Sekolah Tinggi Ilmu Kesehatan Husada Gemilang Tembilahan. Problem yang dihadapi yaitu, pertama, ukuran gedung atau ruangan perpustakaan Akademi Kebidanan Husada Gemilang masih terbilang sempit. Kedua, pendanaan untuk perpustakaan Akademi Kebidanan Husada Gemilang menjadi Sekolah Tinggi Ilmu Kesehatan terutama pengadaan koleksi masih dianggap kurang. Ketiga, jumlah koleksi yang usang lebih banyak dibandingkan koleksi terbaru dan koleksi referensi seperti jurnal majalah masih kurang. Keempat, sumber daya manusia yang dimiliki perpustakaan Akademi Kebidanan Husada Gemilang Tembilahan yang masih kurang, sehingga pekerjaan yang ada sedikit lambat. Kelima, sarana dan prasarana yang dapat menunjang perkembangan perpustakaan manual menjadi digital sangat diperlukan di zaman yang semuanya sudah menggunakan teknologi.
\end{abstract}

Kata kunci : Pustakawan, Hambatan, Perpustakaan, Perguruan Tinggi

\begin{abstract}
:
This article aims to determine the problems of librarians in facing the transition period from the Midwifery Academy to the Husada Gemilang Tembilahan College of Health Sciences. The problems faced are, first, the size of the building or library room at the Husada Gemilang Midwifery Academy is still fairly narrow. Second, the funding for the library of the Husada Gemilang Midwifery Academy to become a College of Health Sciences, especially the procurement of collections, is still considered insufficient. Third, the number of outdated collections is greater than the latest collections and reference collections such as magazine journals are still lacking. Fourth, the human resources owned by the library of the Husada Gemilang Tembilahan Midwifery Academy are still lacking, so the work is a little slow. Fifth, facilities and infrastructure that can support the development of manual libraries to digital are needed in an era where all of them are already using technology.
\end{abstract}

Keywords : Librarian, Obstacle, Library, College

\section{Pendahuluan}

Perpustakaan menurut Undang-undang No 43 tahun 2007 merupakan sebuah lembaga pengelolaan koleksi karya tulis, karya cetak, karya rekam dilakukan sengan profesional mengikuti sistem yang baku untuk kebutuhan pendidikan, penelitian, pelestarian, informasi, dan rekreasi pemustaka. ${ }^{1}$ Sehingga perpustakaan menjadi tempat yang sangat penting bagi seseorang yang membutuhkan informasi karena perpustakaan merupakan tempat segala sumber informasi yang dapat menunjang kebutuhan seseorang baik itu pendidikan, penelitian, pelestarian bahkan bisa menjadi tempat rekreasi bagi semua orang. Di perguruan tinggi perpustakaan dijadikan sebagai jantungnya perguruan tinggi, karena perpustakaan menjadi tempat bagi mahasiswa, dosen dan civitas akademika untuk mendapatkan informasi yang dapat menunjang terlaksananya Tri Dharma pada perguruan tinggi yaitu pendidikan, peneli- 
tian dan pengabdian kepada masyarakat.

Keberadaan dan kondisi perpustakaan perguruan tinggi sangat mempengaruhi kualitas sebuah perguruan tinggi. ${ }^{2}$ Untuk mendapatkan kualitas tersebut maka perpustakaan perlu dikelola oleh sumber daya manusia yang profesional di perpustakaan yang dikenal dengan pustakawan. Menurut undang-undang no 43 tahun 2007 pustakawan merupakan orang yang menempuh pendidikan dan pelatihan kepustakawanan sehingga memiliki kompetensi dalam menjalankan tugas dan tanggung jawab di perpustakaan. Hadirnya pustakawan di perpustakaan ditugaskan agar koleksi-koleksi bahkan fasilitas yang dimiliki perpustakaan dapat dilayankan dan digunakan pemustakanya secara optimal. Karena akan percuma apabila perpustakaan memiliki koleksikoleksi dan fasilitas yang memadai namun tidak dapat dimanfaatkan oleh pemustakanya sehingga fungsi dari perpustakaan tidak dapat berjalan dengan baik. Untuk itu hadirnya pustakawan sangat berperan penting untuk pengoptimalan fungsi perpustakaan.

Perpustakaan Akademi Kebidanan Husada Gemilang Tembilahan merupakan perpustakaan yang berada dalam Instansi AKBID yang berdiri sejak tahun 2007. Pada tahun 2020 AKBID sedang melakukan pengajuan transisi dari instansi AKBID menjadi STIKES (Sekolah Tinggi Ilmu Kesehatan) dengan penambahan satu jurusan yaitu S1 Ilmu Gizi yang akan dibuka pendaftaran pada tahun 2021. Dengan perubahan status instansi bukan hanya perguruan tingginya saja yang akan membuat persiapan dalam menghadapi transisi tersebut, perpustakaanpun memiliki perhatian khusus. Karena perpustakaan merupakan

${ }^{1}$ Undang-undang Republik Indonesia Nomor 43 Tahun 2007 Tentang Perpustakaan

${ }^{2}$ Rizki, J. W. Optimalisasi Fungsi Perpustakaan Perguruan Tinggi Melalui Peran Pustakawan. AL-Kuttab, Vol. 1 No.2, 105. (2013).

${ }^{3}$ Sukistyo Basuki, Pengantar Ilmu Perpustakaan. (Jakarta: Gramedia Pustaka 1993).

${ }^{4}$ Yuyun Yulia, J. G, Materi Pokok Pengembangan Koleksi. ( Jakarta: Universitas Terbuka 2009).

${ }^{5}$ Laksmi, Manajemen Lembaga Informasi: Teori dan Praktik. ( Yogyakarta: Graha Ilmu 2011). jantungnya perguruan tinggi, maka perpustakaan memiliki peran penting dalam menyediakan sumber informasi demi menunjang terlaksananya Tri Dharma perguruan tinggi. Kesiapan pustakawan dalam menghadapi perubahan ini sangat berpengaruh besar dalam pengembangan perpustakaan terutama pengembangan koleksi dan penambahan pemustaka yang harus dilayani. Dari permasalahan yang ada maka penulis membahasa tentang apa saja hambatan yang ditemukan pustakawan pada masa transisi dari AKBID menjadi STIKES.

\section{Tinjauan Pustaka}

\section{Perpustakaan Perguruan Tinggi}

Perpustakaan perguruan tinggi adalah perpustakaan yang terdapat diperguruan tinggi yang memiliki tujuan untuk membantu mencapai keberhasilan dibidang pendidikan, penelitian dan pengabdian masyarakat ketiga tujuan tersebut dinamakan Tri Dharma perguruan tinggi. Jadi perpustakaanlah yang memegang peranan penting dalam mewujudkan tujuan dari sebuah perguruan tinggi. ${ }^{3}$ Pemustaka yang dilayani perpustakaan perguruan tinggi lebih sedikit cakupannya dibandingkan perpustakaan umum yaitu pemustakanya hanyalah sebatas masyarakat yang ada didalam perguruan tinggi tersebut. Namun untuk koleksi yang dimiliki setiap perpustakaan perguruan tinggi tidak bisa disamakan karena kebutuhan setiap perguruan tinggi itu berbeda. Menurut Yuyun dan Janti, koleksi yang dimiliki perpustakaan dapat dibedakan dengan beberapa faktor yaitu:

1) Dilihat dari jenis insatansinya apakah universitas, akademi atau sekolah tinggi.

2) Dilihat dari jenjang pendidikan yang ada di perguruan tinggi tersebut.

3) Dilihat dari program yang diprioritaskan

${ }^{6}$ Laksmi, Manajemen Lembaga Informasi: Teori dan Praktik. ( Yogyakarta: Graha Ilmu 2011).

${ }^{7}$ Peraturan Kepala Perpustakaan Nasional Republik Indonesia Nomor 13 Tahun 2017 tentang Standar Nasional Perpustakaan Perguruan Tinggi 
4) Dilihat dari jumlah mahasiswa

5) Dilihat dari program studi disetiap masingmasing perpustakaan.

Perpustakaan perguruan tinggi merupakan sarana utama yang dapat membantu mewujudkan kegiatan pendidikan, penelitian dan pengabdian. Tanpa adanya peran perpustakaan yang baik, perguruan tinggi tidak akan bisa mewujudkan tujuannya dengan lancar. Karena untuk memiliki kualitas pendidikan dan penelitian yang bagus dipengaruhi oleh kinerja perpustakaan. Perpustakaan perguruan tinggi memiliki empat misi yaitu pelestarian ilmu pengetahuan, fungsi belajar, fungsi pengajar dan fungsi penyebar informasi. ${ }^{5}$ Keempat fungsi itu hanya dapat tercapai apabila perpustakaan mampu menyediakan informasi yang sesuai dengan kebutuhan penggunanya.

Menurut Laksmi koleksi yang terdapat di perpustakaan perguruan tinggi adalah sebagai berikut: ${ }^{6}$

1) Buku bacaan wajib yang digunakan untuk menunjang pembelajaran di kelas.

2) Buku teks yang digunakan sebagai penunjang pembelajaran.

3) Buku referensi yang digunakan untuk penunjang seperti kamus, majalah, ensiklopedia, direktori, dan kliping.

4) Kumpulan artikel maupun jurnal

5) Laporan suatu lembaga

6) Karya ilmiah atau laporan penelitian

Menurut Peraturan Perpustakaan Nasional nomor 13 tahun 2017 Standar Nasional jumlah koleksi yang dimiliki perpustakaan perguruan tinggi yaitu: ${ }^{7}$

1) Judul buku wajib mata kuliah paling sedikit tiga.

2) Judul buku pengayaan dua kali dari buku

\footnotetext{
${ }^{8}$ Darwanto, A. K, Pedoman Penyelenggaraan Perpustakaan Perguruan Tinggi. ( Jakarta: Perpustakaan Nasional 2015).

Sedarmayanti dan Syarifudin Hidayat, Metodologi Penelitian. Bandung: Mandar Maju,2002. Hlm.33
}

wajib

3) Koleksi audio visual menyesuaikan kebutuhan perguruan tinggi

4) Koleksi elektronik (e-resource) menyesuaikan kebutuhan perguruan tinggi

5) Jurnal ilmiah paling sedikit dua judul, berlangganan maupun menerima secara berkala setiap program studi

6) Makalah ilmiah paling sedikit satu judul berlangganan maupun menerima secara berkala setiap program studi

7) Repositori yaitu hasil karya ilmiah civitas akademik skripsi, tesis, disertasi, makalah, seminar, simposium, konferensi, laporan penelitian, laporan pengabdian masyarakat, artikel yang dipublikasikan, majalah atau buletin kampus.

Standar sarana dan prasarana perpustakaan perguruan tinggi juga diatur dalam Peraturan Perpustakaan Nasional nomor 13 tahun 2017 sebagai berikut:

1) Luas ruangan perpustakaan paling sedikit 0,5 $\mathrm{m} 2 \mathrm{x}$ banyak mahasiswa.

2) Komposisi ruangan perpustakaan perguruan tinggi dibagi empat (4) bagian yaitu area koleksi $45 \%$, area pemustaka $25 \%$ area kerja $10 \%$ area penunjang ( toilet, ruang tamu, seminar, lobi) $20 \%$

3) Temperatur ruangan koleksi, ruangan baca dan kerja 20' - 25' celcius.

Dana yang dimiliki perpustakaan perguruan tinggi dengan mengalokasikan anggaran perpustakaan setiap tahun yaitu $5 \%$ dari total anggaran perguruan tinggi di luar pengembangan fisik dan gaji.

\section{Pustakawan}

Menurut undang-undang nomor 43 tahun 2007 pustakawan merupakan orang yang memiliki kompetensi di bidang perpustakaan yang diperoleh melalui pendidikan atau pelatihan kepustakawanan yang memiliki tugas dan tanggung jawab untuk melaksanakan pengelolaan dan pe- 
layaan perpustakaan. Kompetensi pustakawan harus selalu diperhatikan dan ditingkatkan terus menerus mengikuti perkembangan ilmu pengetahuan dan teknologi. Sumber daya manusia yang ada di perpustakaan perguruan tinggi yaitu pustakawan, tenaga teknis perpustakaan dan kepala perpustakaan (Darwanto, 2015). ${ }^{8}$ Tugas pustakawan ialah melakukan kegiatan kepustakawanan seperti pengelolaan, pelayanan, dan pengembangan perpustakaan demi menunjang tri dharma perguruan tinggi. Kualifikasi akademik pustakawan keterampilan yaitu:

1) Menempuh pendidikan paling rendah Diploma II ilmu peprustakaan

2) Menempuh pendidikan paling rendah Diploma II bidang lain

Sedangkan untuk kualifikasi pustakawan keahlian yaitu:

1) Menempuh pendidikan paling rendah Sarjana (S1) ilmu perpustakaan

2) Menempuh pendidikan paling rendah Sarjana (S1)/ Diploma IV bidang lain

Jumlah pustakawan mengikuti standar nasional yang ditetapkan Kepala Perpustakaan Nasional ialah ditentukan dengan melihat jumlah mahasiswa yang ada di perguruan tinggi yaitu satu pustakawan untuk lima ratus pemustaka.

\section{Metode Penelitian}

Artikel ini menggunakan penelitian kualitatif deskriftif, yaitu penelitian yang bertujuan untuk menggambarkan dan menjelaskan segala sesuatu dengan apa adanya. Sehingga objek yang dikaji dapat dibahas secara mendalam. ${ }^{9}$ Untuk mendapatkan data di lapangan penulis melakukan wawancara dengan pustakawan Akademi Kebidanan Husada Gemilang Tembilahan.

\section{Hasil dan Pembahasan}

Hasil yang didapatkan saat melakukan wawancara kepada pustakawan di perpustakaan Akademi Kebidanan Husada Gemilang Tembilahan ternyata problem yang ditemukan oleh pustakawan dalam masa transisi untuk menjadi Sekolah Tinggi Ilmu Kesehatan yaitu, kurangnya sumber daya manusia di perpustakaan, lokasi atau luas gedung, dana, koleksi dan sarana dan prasarana.

\section{Gedung/ruangan perpustakaan}

Perpustakaan AKBID berada digedung utama yang terletak dilantai 2 yang saat ini berukuran $8 \times 6 \mathrm{~m}$. Ruangan perpustakaan AKBID ini hanya memiliki satu ruangan saja tanpa ada tempat sekat lainnya seperti ruang koleksi, ruang pemustaka, ruang kerja dan ruangan penunjang. Hanya ada satu ruangan yang di bagi menjadi tempat koleksi, tempat baca pemustaka, dan meja kerja pustakawan. Sehingga memperlihatkan keadaan gedung perpustakaan menjadi sangat sempit terlebih dikarenakan banyak barang yang malah disimpan kedalam perpustakaan. Karena perpustakaan tidak memiliki gudang sehingga koleksi yang tidak dilayankanpun masih diletakkan di dalam perpustakaan walaupun disimpan di dalam kotak sehingga membuat ruangan perpustakaan menjadi sempit. Apabila saat akan menjadi ruangan perpustakaan ini harus ditambah luasnya karena akan ada penembahan koleksi dan akan menambah rak untuk buku jurusan baru dan akan memakan banyak tempat selain itu juga ruang baca untuk pemustaka juga sangat diperlukan karena akan pasti banyak penambahan pemustaka. jika dilihat untuk saat ini saja perpustakaan sudah sempit dengan meja baca yang disediakan dan dibutuhkan ruangan besar. Namun untuk saat solusi penambahan ruangan belum disetujui karena mengingat ruangan yang dimiliki perguruan tinggi masih sangat terbatas sekali. Sehingga masih mencari cara bagaimana memanfaatkan luas ruangan yang ada namun dapat memberikan tempat rak yang akan disediakan untuk menampung koleksi baru terutama untuk jurusan yang baru dibukan di perguruan tinggi ini. 


\section{Dana}

Dana menjadi problem di perpustakaan terutama ketika akan melakukan pengadaan koleksi. Karena perguruan tinggi ini akan menjadi Sekolah Tinggi Kesehatan maka akan menambahkan jurusan baru yang akan membutuhkan banyak koleksi baru terutama untuk jurusan yang baru dibuka. Namun, alokasi untuk koleksi masih sangat dibutuhkan. Pada desember 2020 pengadaan koleksi perpustakaan bersumber dari uang sumbangan dari alumni yang lulus pada tahun 2020 .

\section{Koleksi}

Koleksi perpustakaan merupakan segala bentuk informasi baik dalam bentuk tercetak, bentuk tulis, bentuk rekam yang memiliki nilai pendidikan, dihimpun, diolah dan dilayankan. Koleksi merupakan pemeran utama yang penting diperpustakaan. Sehingga koleksi yang ada diperpustakaan haruslah sesuai dengan kebutuhan penggunanya selain itu koleksi yang dimilikipun haruslah koleksi yang up to date demi menunjang pengetahuan pemustakanya. Di perpustakaan AKBID banyak ditemukannya koleksi-koleksi yang memiliki tingkat keusangan yang tinggi dan juga dilihat dari buku peminjaman buku tersebut jarang dipinjam siswa bahkan ada koleksi yang tidak pernah dipinjam oleh mahasiswanya. Untuk itu perpustakaan perlu melakukan pengadaan koleksi dengan melihat kebutuhan penggunanya dan juga keterbaruan dari koleksi yang disediakan.

\section{Sumber Daya Manusia}

Perpustakaan AKBID masih sangat kekurangan sumber daya manusia dalam pengelolaan perpustakaan. Karena perpustakaan ini hanya memiliki satu (1) pustakawan tanpa memiliki kepala perpustakaan, tenaga teknis perpustakaan dan tenaga administrasi. Sehingga pustakawan tersebut merangkap semua jabatan dan tugas yang dilakukan seorang diri. Padahal berdasarkan Peraturan Kepala Perpustakaan Nasional Republik Indonesia nomor 13 tahun 2017 tentang standar nasion- al perpustakaan perguruan tinggi bahwa tenaga perpustakaan itu terdiri dari kepala perpustakaan, pustakawan, tenaga teknis perpustakaan dan tenaga administrasi yang memiliki kualifikasinya masing-masing. Namun karena peprustakaan ini hanya memiliki satu tenaga perpustakaan membuat pekerjaaan yang ada diperpustakaan menjadi lamban dan terkesan tidak ada perubahan yang dilakukan di dalam perpustakaan. Perpustakaan AKBID masih sangat kekurangan sumber daya manusia dalam pengelolaan perpustakaan.

\section{Sarana dan Prasarana}

Perpustakaan AKBID Husada Gemilang masih kekurangan sarana prasarana penunjang untuk koleksi. Sarana penunjang koleksi tersebut ialah penerapan penggunaan sistem katalog daring yang digunakan untuk memudahkan pemustakanya dalam menemukan koleksi yang dibutuhkannya. Selain itu perpustakaan juga masih manual sehingga peminjaman dan pengembalian koleksi masih manual dengan menulis di buku peminjaman maupun pengembalian buku. Perpustakaan masih belum terautomasi. Selain itu karena gedung yang sempit sehingga perpustakaan masih kekurangan rak untuk koleksi yang masih disimpan di dalam kardus, sedangkan koleksi seperti karya ilmiah mahasiswanya terus masuk ke perpustakaan dan membutuhkan tempat yang banyak. Perpustakaan juga membutuhkan pendingin ruangan dikarenakan pendingin ruangan yang ada sekarang sudah tidak terasa dingin lagi jika digunakan.

\section{Kesimpulan dan Saran}

Berdasarkan temuan yang penulis paparkan di atas, maka problematika yang dihadapi oleh pustakawan Akademi Kebidanan Husada Gemilang Tembilahan dalam menghadapi transisi Perguruan Tinggi menuju Sekolah Tinggi Ilmu Kesehatan. Pertama, luas gedung perpustakaan saat ini tidak sesuai dengan standar ukuran perpustakaan perguruan tinggi apalagi akan terjadi penambahan 
koleksi jurusan baru sehingga membutuhkan ruangan yang lebih luas untuk meletakkan rak dan koleksi yang ada. Selain itu ruangan baca untuk pemustaka juga dibutuhkan karena pemustaka juga bertambah banyak. Kedua, perpustakaan membutuhkan dana untuk melakukan pengadaan buku yang diutamakan ialah koleksi untuk jurusan baru yang akan dibuka. Pengadaan untuk koleksi baru dananya diambil dari uang iuran dari alumni 2020. Yang artinya perpustakaan hanya bisa melakukan pengadaan koleksi dengan terbatas sesuai dana yang dimiliki dari uang iuran yang diambil dari alumni 2020. Ketiga, di perpustakaan AKBID banyak ditemukannya koleksikoleksi yang memiliki tingkat keusangan yang tinggi dan juga dilihat dari buku peminjaman buku tersebut jarang dipinjam siswa bahkan ada koleksi yang tidak pernah dipinjam oleh mahasiswanya. Keempat, Perpustakaan AKBID masih sangat kekurangan sumber daya manusia dalam pengelolaan perpustakaan. dimana hanya ada satu (1) sumber daya manusianya yang merangkap semua jabatan dan tugas yang ada di perpustakaan. Padahal sesuai standar perguruan tinggi sumber daya manusia yang ada di perpustakaan perguruan tinggi ialah kepala perpustakaan, pustakawan, tenaga teknis perpustakaan dan tenaga administrasi. Kelima, sarana dan prasarana penunjang perpustakaan untuk beralih dari manual menuju automasi seperti komputer yang akan digunakan jika penerapan sistem katalog online telah dilayankan untuk pemustaka. alat peminjaman dan pengembalian koleksi secara mandiri.

\section{Referensi}

Basuki, S. (1993). Pengantar Ilmu Perpustakaan. Jakarta: Gramedia Pustaka.

Darwanto, A. K. (2015). Pedoman Penyelenggaraan Perpustakaan Perguruan Tinggi. Jakarta: Perpustakaan Nasional.

Laksmi. (2011). Manajemen Lembaga Informasi: Teori dan Praktik. Yogyakarta: Graha Ilmu.

Peraturan Kepala Perpustakaan Nasional Republik Indonesia Nomor 13 Tahun 2017 tentang Standar Nasional Perpustakaan Perguruan Tinggi

Rizki, J. W. (2013). Optimalisasi Fungsi Perpustakaan Perguruan Tinggi Melalui Peran Pustakawan. AL-Kuttab, Vol. 1 No.2, 105.

Undang- undang Republik Indonesia Nomor 43 Tahun 2007 Tentang Perpustakaan

Yuyun Yulia, J. G. (2009). Materi Pokok Pengembangan Koleksi. Jakarta: Universitas Terbuka. 